\title{
Ciber COMO LOCAL DE TRABALHO: O PROBLEMA (OU A SOLUÇÃO?) DO TELETRABALHO TRANSNACIONAL
}

\author{
Denise Pires Fincato ${ }^{1}$ \\ Manoela de Bitencourt ${ }^{2}$
}

\begin{abstract}
Resumo
Analisa-se a situação dos teletrabalhadores transnacionais, especialmente enfocando a lei a ser aplicada à sua contratação. Parte-se da premissa de que o espaço de trabalho, no teletrabalho, é um local virtual, denominado ciberespaço, tornando, por isso, difícil a aplicação do elemento de conexão territorial ao contrato internacional, gerando o problema estudado. O princípio da norma mais favorável inicialmente se afigura como mais apropriado. No entanto, é preciso testar se sua aplicação não geraria violação ao princípio da igualdade. Conclui-se pela aplicação da ponderação, sugerindo-se resolução casuística, na qual possa ser aplicada a norma de nacionalidade do teletrabalhador ou a norma do local onde o mesmo presta seus serviços, buscando sempre sua proteção e progressão social, aliado ao impedimento do dumping social.
\end{abstract}

Palavras-Chave: Teletrabalho Transnacional. Norma aplicável. Proteção. Dumping Social.

\section{INTRODUÇÃO}

O texto é resultado de pesquisas na interseção Direito do Trabalho, Direito Internacional Privado e Direito Constitucional, no contexto da Globalização e dos efeitos das Tecnologias de Informação e Comunicação.

Analisa-se a problemática do trabalho remoto, telemático, ao qual convencionou-se chamar teletrabalho, especialmente em sua face transnacional.

Indaga-se qual a lei aplicável ao teletrabalho transnacional, especialmente aquele que ocorre no espaço não físico, cunhado de Ciberespaço. A doutrina ainda se debate, a jurisprudência ainda não enfrentou o tema. Este artigo ensaia respostas a partir do método hipotético-dedutivo.

\footnotetext{
${ }^{1}$ Doutora (2001) em Direito. Professora e Pesquisadora no PPGD da PUCRS, titular das disciplinas de Metodologia da Pesquisa Jurídica e Novas Tecnologias: Processo e Relações de Trabalho.Professora na Graduação da PUCRS, disciplinas Direito do Trabalho, Direito Processual e Prática Trabalhista e Direito do Trabalho e Seguridade Social. Coordenadora do Grupo de Pesquisas Novas Tecnologias: Processo e Relações de Trabalho (PUCRS/CNPq). E-mail: dpfincatol@gmail.com

${ }^{2}$ Doutora em Direito. Professora e Pesquisadora no PPGD da PUCRS. Coordenadora do Grupo de Pesquisas Novas Tecnologias, Processo e Relações de Trabalho.E-mail: manoela@bitencourtadv.br vol. 08, nº. 04, Número Especial. Rio de Janeiro, 2015.pp. 2237-2263 
Parte-se do pressuposto de que é possível a aplicação de duas sistemáticas: a igualitária ou a protetiva. Pela perspectiva igualitária, nem sempre se teria justiça social e, não raro, se estaria chancelando iniciativas empresariais que configurariam o dumping social.

Espera-se, com este estudo, contribuir ao amadurecimento e fomentar o enfrentamento do tema e do fato, cada vez mais corriqueiro, no cenário das empresas de tecnologia e multinacionais.

\section{EFICÁCIA DA LEI TRABALHISTA NO ESPAÇO E O TELETRABALHO TRANSNACIONAL}

A pactuação de contratos internacionais de trabalho, especialmente na modalidade de teletrabalho transnacional, implica na possibilidade de incidência múltipla de normas, oriundas no mais das vezes de Estados e sistemas jurídicos distintos. É legítima a dúvida do operador em um caso concreto dessa natureza, indagando-se acerca de qual regramento deve ser aplicado ao contrato: o do domicílio do trabalhador, da sede do empregador, do local onde prestado o serviço (e se esse espaço for virtual?), do local onde o resultado do trabalho se produz?

Nesse cenário, merecem destaque as palavras de Dallegrave Neto (2000, p. 69):

Muito se fala, hoje, em migração de trabalhadores. A lufa-lufa das empresas transnacionais implica quebrar fronteiras geográficas em busca de novos consumidores e mão-de-obra barata. Caem-se as barreiras alfandegárias, estimula-se o investimento do capital estrangeiro, facilita-se a importação e a exportação do trabalho braçal, técnico e intelectual. Apanágios de um mundo globalizado. Um mundo onde a lei de mercado e a busca pela maximização do lucro sobrepõem-se às questões éticas, culturais e humanitárias.

O avanço do fenômeno globalizatório, as crises econômicas setoriais/globais e a popularização do acesso às tecnologias de comunicação e informação, tornam as relações de trabalho internacionais mais corriqueiras e facilitadas. Há um intenso trânsito de trabalhadores (e de trabalho), em correntes que buscam espaços sócio-políticos mais convenientes para o momento econômico. Entre outros fatores, as crises econômicas que atingem determinadas regiões determinam movimentos de busca por melhores condições de vida e trabalho, gerando a transnacionalização das relações de trabalho. Nesse sentido, não é rara a contratação de brasileiros por empresas transnacionais, assim como a de estrangeiros por empresas nacionais. Com isso, surge a possibilidade de incidência de mais de uma lei à relação jurídico trabalhista. ${ }^{3}$

Nesse sentido, bem ilustra Amauri Mascaro Nascimento (2003, p.90):

As relações de trabalho internacionais apresentam problemas específicos decorrentes da mobilidade da força de trabalho entre as fronteiras à procura de novo emprego ou em sequência do mesmo emprego, pondo-se o trabalhador, em outro país, na situação de

\footnotetext{
${ }^{3}$ Os constantes movimentos migratórios do homem, decorrentes de crises econômicas, marcadamente pela falta de postos de trabalho e contraprestação digna são fatores que promovem a exportação de mão-de-obra e de trabalhadores à outros países, gerando crises e conflitos internos a serem resolvidos pelas normas de Direito Internacional Privado que passam a se integrar no âmbito do Direito da Nacionalidade, e por essa razão a importância de se ter clara as regras específicas adotadas por parte do país de acolhida do imigrante (CARDONA, 2006, p.21).
} 
estrangeiro submetido, até mesmo e conforme o caso, a três ordenamentos jurídicos, o do Estado em que está prestando o serviço, o do seu país de origem e o ordenamento supranacional internacional, em alguns casos comunitário.

Assim, pode-se ter uma diversidade de leis aplicáveis para a regulação da relação trabalhista de tipo transnacional, tais como: a lei do local da prestação dos serviços, a lei do país de origem do empregado, a lei do local do estabelecimento da empresa, dentre outras.

Para a boa compreensão deste estudo, cumpre registrar que se entende por relações internacionais de trabalho, as que "podem ser delimitadas em mais de um âmbito, vinculadas pela ideia comum, presente em todas as relações jurídicas de trabalho que são encontradas nesta matéria, que é o seu desenvolvimento em mais de um país"(NASCIMENTO 2003, p.91).

Portanto, o trabalho prestado em mais de um país é considerado uma relação internacional de trabalho, visto que ultrapassa as barreiras de um único Estado, propagando-se causas e efeitos em diversos territórios. Porém, a hipótese de se ter um estrangeiro num país não configura uma relação internacional de trabalho, pois esta nada mais será do que uma relação de trabalho no território de um Estado, submetendo esse estrangeiro às normas do país da prestação do trabalho, em decorrência do princípio da territorialidade.

O teletrabalho transnacional é contrato internacional de trabalho e reveste-se em problema jurídico de análise e solução complexas.

No cenário que se apresenta, vislumbra-se necessário o diálogo entre as fontes. O direito do trabalho e o Direito Internacional Privado têm de reunir elementos para solucionar um possível conflito de leis trabalhistas no espaço. Peres (2004, p.35) afirma com propriedade que :

[...] globalização da economia incentiva cada vez mais o trânsito internacional de trabalhadores especializados - técnicos e executivos que passam a compor uma fonte mundial de recursos humanos para as empresas. Aumentarão, em consequência, os conflitos de leis do trabalho no espaço, o que reclama novos diálogos do Direito Internacional Privado com o Direito do Trabalho condizentes com esse panorama.

Diante deste contexto, atual e emergente, vislumbram-se os contratos transnacionais de teletrabalho, cujos eventuais conflitos normativos serão solucionados, para os fins desse estudo, pela conjugação de preceitos do Direito Internacional Privado e do direito do trabalho.

\section{O CONFLITO DE LEIS TRABALHISTAS}

O teletrabalho transnacional é o trabalho realizado à distância, por meio de instrumentos telemáticos e informacionais a um empregador que se encontra sediado em outro país. Desse modo, possível é que uma multiplicidade de leis oriundas de países distintos incidam hipoteticamente sobre essa relação jurídica, o que poderá provocar um hipotético conflito de leis. Assim, deve-se analisar os possíveis elementos de conexão aptos a solucionar esse conflito, o que se pretende nas páginas subsequentes. 
Primeiramente, é necessário trazer uma definição de teletrabalho transnacional ou transfronteiriço. Com efeito, o teletrabalho transnacional pode gerar a possibilidade de incidência de mais de uma lei sobre o contrato: a lei do local onde se deu a contratação; a(s) lei(s) do(s) local(is) no(s) qual(is) o contrato vai ser executado; a lei do local onde os resultados laborais estão sendo recebidos (sede do empregador), dentre outras, surgindo, assim, um conflito de leis trabalhistas no espaço. Nesse diapasão é que este estudo se propõe a analisar qual delas deva ser aplicada à relação jurídica transnacional. Vecchi (2004, p.147) explica a razão desses conflitos:

Com a integração econômica cada vez maior, tendo em vista os postulados da globalização, cada vez tende a se tornar mais comum o conflito de normas jurídicas a serem aplicadas em um caso concreto, pois trabalhadores podem ser contratados em Estados diversos para prestar serviços em outros estados.

E a solução para os conflitos decorrentes da possibilidade de aplicação simultânea de leis oriundas de diferentes ordenamentos jurídicos é objeto de estudo do ramo específico da ciência jurídica, denominado Direito Internacional Privado, em que "[...]. Através de suas normas, cada país - por seu direito interno - elege um determinado elemento da relação (elemento de conexão) e estabelece que o ordenamento jurídico com o qual este elemento possua contato mais íntimo regerá toda a relação" (CUNHA, 2006, p.3).

Assim, compete ao Direito Internacional Privado resolver os conflitos de leis no espaço, na hipótese de possibilidade de incidência de mais de uma norma sobre a relação jurídica, advindas estas de ordenamentos jurídicos diferentes.

Com os postulados do Direito Internacional Privado, é possível solucionar os conflitos de leis decorrentes da aplicabilidade, a um mesmo caso concreto, de mais de um ordenamento jurídico. Strenger (1996, p.50 $)^{4}$ explica que "[...] o direito local colide com outro direito local e no meio disto tudo está o nacional ou o estrangeiro, mas existe sempre um conflito a ser resolvido, uma colisão a ser solucionada”.

O Direito Internacional Privado, portanto, "é a ciência jurídica que estuda e rege as condições jurídicas do estrangeiro, bem como a aplicação das leis estrangeiras em outro território, e também dos conflitos existentes entre referidas leis alienígenas com as leis locais" (AMORIM, 2002, p.7). Nesse sentido, também são os ensinamentos de Haroldo Valladão (1980, p.38): "O DIP é o ramo da ciência jurídica que resolve os conflitos de leis no espaço, disciplinando os fatos em conexão no espaço com leis divergentes e autônomas".

É via Direito Internacional Privado que se determina a norma competente na hipótese de serem potencialmente aplicáveis duas normas diferentes à mesma situação jurídica, registrando a necessidade de identificação de um "elemento de estraneidade" ao direito nacional's . Assim, no objeto desse estudo, em razão

\footnotetext{
${ }^{4}$ STRENGER, Irineu. Direito Internacional Privado. São Paulo: LTr, 1996, p. 50.

${ }^{5}$ Sobre a questão do elemento de estraneidade existente num contrato internacional, esclarece Strenger (1996, p.54) "Assim, o conjunto de regras de direito interno que determinam as leis aplicáveis às relações jurídicas concernentes aos particulares, quando intervém dado estrangeiro, chama-se de Direito Internacional Privado. Direito que se diz privado, porque, imediatamente, relativo a particulares, e não ao Estado; internacional, podem concorrer dados não-nacionais. O contrato que assinei em França contém um vol. 08, nº. 04, Número Especial. Rio de Janeiro, 2015.pp. 2237-2263 
dessa multiplicidade de ordenamentos jurídicos potencialmente aplicáveis, viável a ocorrência de um conflito de leis, podendo a relação ser regida por mais de um sistema jurídico, o que carece de resolução em prol da segurança jurídica e da justiça (ARAUJO, 2004, p.30).

Depreende-se, portanto, que o chamado "elemento de estraneidade" presente nos contratos internacionais caracteriza-se pela existência de elementos estranhos a uma relação jurídica constituída no Brasil, v.g., pois ao celebrar um contrato no Brasil com uma empresa estrangeira, está-se diante de um contrato internacional pela presença de um elemento estrangeiro, ou seja, não nacional. A respeito, afirma Araújo (2004, p.5):

A multiplicação e a diversidade de sistemas jurídicos são dados de fato, e cada Estado possui seu ordenamento jurídico, em princípio aplicável dentro de suas fronteiras. Tal limitação não é absoluta, pois há relações que extrapolam os limites de determinado Estado. Essas relações geram o tradicionalmente denominado conflito de leis no espaço, cuja resolução é tarefa precípua do Direito Internacional Privado.

A incidência de leis nacionais aos contratos celebrados dentro de um Estado justifica-se por sua aplicação compulsória dentro dos limites territoriais desse país, sendo as fronteiras com outros países o limite do âmbito de aplicação. Todavia, isso não é absoluto, pois existem relações jurídicas que ultrapassam as barreiras de um Estado (e por vezes, até de dois ou três Estados), como é o caso do teletrabalho transnacional, possibilitando que outro ordenamento jurídico (ou diversos ordenamentos) seja(m) aplicado(s) ao contrato.

Os conflitos de leis são resolvidos pelo Direito Internacional Privado. Quando se tem uma dúvida sobre qual lei aplicar ao caso concreto, se a lei nacional ou a lei estrangeira, devem-se utilizar algumas regras de conexão para resolver o problema (CASSAR, 2003, p.825).

Para explicar esse fenômeno do conflito espacial de leis, notadamente na área trabalhista, explica Nascimento (2005, p.333):

Os conflitos de leis em matéria trabalhista decorrem não só do deslocamento de mão-deobra, mas do desenvolvimento dos transportes internacionais, da necessidade de técnicos estrangeiros nos países de menor desenvolvimento, da crescente internacionalização do comércio, da extensão do comércio, da extensão internacional das atividades das empresas com filiais em diversas partes do mundo, daí por que não é pequeno o número de assalariados em razão dos quais surgem questões de aplicação espacial da lei.

O trabalhador que é contratado no Brasil para trabalhar no exterior ou, já trabalhando no Brasil e é transferido para laborar em outro país, desencadeia um possível conflito de leis trabalhistas, aplicando-se, nessas circunstâncias, as normas do Direito Internacional Privado, que indicarão o ordenamento jurídico para reger tal relação, solucionando, assim, o problema conflitual (MELLO, 2005, p.30).

desses elementos estrangeiros: o lugar em que fiz. Se assinei no Brasil com um francês, o lugar é nacional, mas há o elemento estrangeiro, que é essa outra pessoa, com quem contratei, de nacionalidade francesa [...]." 
Para resolver determinado conflito de leis no espaço (adotando uma das leis aplicáveis ao caso concreto), deve-se primeiramente definir o critério que irá orientar a escolha da norma aplicável, o qual é fornecido pelo elemento de conexão (MALLET, 1998, p. 330). Nesse sentido, é o pensamento de Dallegrave Neto (2000, p.70) quando afirma: "Para se chegar a lei que será aplicada ao caso concreto, deve-se saber qual elemento de conexão irá prevalecer. Por elemento de conexão se entende o critério jurídico utilizado para delimitar a lei incidente nos casos de conflito". O elemento de conexão é, assim, o "fator de vinculação, de ligação a determinado sistema jurídico, porque é através dele que sabemos qual o direito aplicável. É o vínculo que relaciona um fato qualquer a determinado sistema jurídico", conforme aduz Strenger (1996, p.352).

Portanto, em todos os ordenamentos jurídicos existem regras próprias de cada país para regular determinada categoria de situação conectada com outros ordenamentos jurídicos, as quais se chamam de regras de conexão ou normas indiretas (ARAUJO, 2004, p.25).

Como o contrato de teletrabalho transnacional está submetido a ordenamentos jurídicos diferentes, fazse necessário primeiramente eleger um elemento de conexão, ou seja, escolher o critério que determinará a lei que vai ser aplicada ao contrato para solucionar, assim, o problema jurídico. A partir disto, verifica-se, dentre os possíveis ordenamentos jurídicos incidentes ao contrato de teletrabalho transnacional, o elemento de conexão mais próximo ou mais adequado, apto a solucionar o conflitos de leis, o que será analisado a seguir.

\section{DIREITO APLICÁVEL}

A relação jurídica de teletrabalho transnacional pode ser submetida a mais de um ordenamento jurídico nacional para sua regulamentação, na medida em que está presente um elemento de estraneidade. Com efeito, surge, no plano transnacional, um conflito de leis trabalhistas, o qual deve ser resolvido pelo Direito Internacional Privado (do trabalho), que vai indicar o ordenamento competente, ou seja, vai apontar qual norma (ou conjunto normativo) será aplicável à relação jurídica trabalhista em concreto.

No Direito Civil, a título ilustrativo, as regras sobre os direitos da personalidade, nome, capacidade e os direitos de família são determinadas pela lei do país em que for domiciliada a pessoa ${ }^{6}$.

Entretanto, no Direito do Trabalho, os elementos estrangeiros que internacionalizam a relação jurídica de emprego mais comuns são a nacionalidade do empregado, a nacionalidade do empregador, o lugar da sede da empresa, o local da prestação de serviços e o foro da celebração do contrato (PERES, 2004, p.43).

Segundo os ensinamentos de Dallegrave Neto (2000, p.70), diante de um conflito de leis no espaço, necessita-se de um critério jurídico para determinação da lei aplicável ao caso concreto. Os critérios, criados pelo

\footnotetext{
${ }^{6}$ Art. 70 "A lei do país em que for domiciliada a pessoa determinas as regras sobre o começo e o fim da personalidade, o nome, a capacidade e os direitos de família”. (BRASIL, Decreto-Lei n. 4.657, 1942).
} 
direito, são o da nacionalidade do agente; a lex rei sitae (a lei de situação da coisa); a lex loci regit actum (a lei do local da feitura do ato), previsto no art. $9^{\circ}$ da Lei de Introdução às Normas do Direito Brasileiro (DL n. 4.657/42 ) e, por fim, o critério da territorialidade (local de prestação de serviços).

Além disso, há também o critério da autonomia da vontade das partes, estabelecendo que as próprias partes podem eleger a lei aplicável ao seu contrato, o que, no Direito do Trabalho Brasileiro, está previsto no art. 444 da Consolidação das Leis do Trabalho ${ }^{7}$, circunstância que pode precarizar a natureza protetiva das normas que regem as relações de emprego. Em nível internacional, tem-se a Convenção de Roma que, no art. $3^{\circ}-1^{8}$, privilegia a vontade das partes na escolha da lei a ser aplicada ao contrato. Tal critério não pode ser aplicado, no Direito do Trabalho, se não observada a legislação que for mais favorável ao trabalhador.

Segundo Octávio Bueno Magano (1987, p. 917), a regra a ser aplicada aos casos de conflito de leis trabalhistas no espaço é a da lex loci laboris, ou seja, a lei do lugar da execução do contrato de trabalho, normalmente idêntica ${ }^{9}$ à lei do país de prestação dos serviços pelo trabalhador, pois não se concebe a ideia de se aplicarem ordenamentos jurídicos diversos a trabalhadores de/em um mesmo território.

O art. 198 do Código de Bustamante dispõe, "também é territorial a legislação sobre acidentes de trabalho e proteção social do trabalhador" ${ }^{10}$.

A Convenção de Roma no seu art. $6^{\circ}$, 2, letra a ${ }^{11}$ também dispõe nesse sentido. Assim, para solucionar um conflito de leis no espaço, em regra, aplica-se o critério da territorialidade. Essa questão já foi objeto de Súmula do Tribunal Superior do Trabalho. A Súmula 207 do TST (hoje cancelada) previa que "a relação jurídica trabalhista é regida pelas leis vigentes no país da prestação de serviço e não por aquelas do local da contratação".

Sérgio Pinto Martins (2005, p.85) ressalta que:

[...] a atual Lei de Introdução ao Código Civil não teria revogado o art. 198 do Código de Bustamante, pois a lei geral não revoga a especial $\left(\$ 2^{\circ}\right.$, do art. $2^{\circ}$ da Lei de Introdução ao Código Civil). Assim, prevalece a regra contida no art. 198 do Código de Bustamante para efeito da solução de conflitos de leis no espaço, aplicando-se a lei do local da prestação dos serviços. (grifou-se)

Segundo Arnaldo Sussekind (2005, p.39) a justificativa para a aplicação da territorialidade é a igualdade:

\footnotetext{
${ }^{7}$ Art. 444 - As relações contratuais de trabalho podem ser objeto de livre estipulação das partes interessadas em tudo quanto não contravenha às disposições de proteção ao trabalho, às convenções coletivas que lhes sejam aplicáveis e às decisões das autoridades competentes.

${ }^{8}$ Artigo $3^{\circ}$ - Liberdade de escolha - 1- O contrato rege-se pela lei escolhida pelas Partes. Esta escolha deve ser expressa ou resultar de modo inequívoco das disposições do contrato ou das circunstâncias da causa. Mediante esta escolha, as Partes podem designar a lei aplicável à totalidade ou apenas a uma parte do contrato.

${ }^{9}$ Com o teletrabalho, o local de prestação de serviços pode ser uma plataforma digital (ciberespaço), o que poderá tornar o local diverso do país de domicílio do trabalhador. Ademais, o próprio trabalhador pode não possuir um local fixo de prestação de serviços (teletrabalho nômade) o que poderia implicar na aplicação sucessiva de diversos ordenamentos jurídicos.

${ }^{10}$ BRASIL, Convenção de Direito Internacional Privado, 1928

${ }^{11}$ Art. $6^{\circ}$ Contrato individual de trabalho [...] 2- Não obstante o disposto no art. $4^{\circ}$, e na falta de escolha feita nos termos do art. $3^{\circ}$,o contrato de trabalho é regulado: a) Pela lei do país em que o trabalhador, no cumprimento do contrato, presta habitualmente o seu trabalho, mesmo que tenha sido destacado temporariamente para outro país.
} 
[...] a tendência universal de se assegurar igualdade de direitos aos nacionais e estrangeiros que prestam serviços, como empregados, em determinado país e a circunstância de ser a legislação do trabalho constituída, em parte, de normas de direito público e, em parte, de normas de direito privado que, no entanto, possuem, geralmente, o caráter de ordem pública, fundamentam o generalizado apelo à lei de lugar da prestação do trabalho.

Conforme diz o autor, o tratamento aos empregados deve ser dado de maneira igual, sem distinção nenhuma. Mesmo sendo menos benéfica a lei do país da execução do serviço em face da lei da origem do trabalhador, pela aplicação do princípio da territorialidade, esta é a que vai ser a competente, em razão de garantir a igualdade entre todos.

Christiane Bernardes de Carvalho Mello (2005, p. 39) afirma que

[...] seria realmente confuso e injusto imaginar, por exemplo, no nosso país (ou em qualquer outro) uma empresa que possua trabalhadores de várias nacionalidades e, no que concerne, por exemplo, às horas extras, tenha que dar tratamento diferenciado para brasileiros, japoneses e espanhóis. Esses trabalhadores estrangeiros devem sujeitar-se às normas, aos costumes e à realidade do país em que está sendo executado o labor.

Em razão, portanto, dessa busca de igualdade no trabalho para estrangeiros e nacionais, consolidou-se o entendimento no sentido de que a lei aplicável a essa relação há de ser a do lugar da execução do serviço.

A corrente doutrinária formada por Arnaldo Sussekind (1984, p. 153) também entende que a norma aplicável para reger uma relação jurídica trabalhista é aquela do local da prestação de serviço. Segundo ele, "a 'lex loci executionis', que é a [lei] do país em que o trabalho está sendo, atualmente, prestado, há de ser a competente, por conseguinte, para reger a relação jurídica como um todo."

Assim, de acordo com este entendimento, as relações dos teletrabalhadores que laboram em nível internacional ${ }^{12}$ devem ser regidas pela lei do país onde se está prestando o serviço, ou seja, a mesma lei que se aplica aos naturais daquele país.

O Decreto Real no 3/2012 ${ }^{13}{ }^{14}$ da Espanha, hoje convalidado em Lei, reformou a regulação de teletrabalho naquele país e no seu artigo 13 , item 3 , prevê que:

Los trabajadores a distancia tendrán los mismos derechos que los que prestan sus servicios en el centro de trabajo de la empresa, salvo aquéllos que sean inherentes a la realización de la prestación laboral en el mismo de manera presencial. En especial, el trabajador a distancia tendrá derecho a percibir, como mínimo, la retribución total establecida conforme a su grupo profesional y funciones.

A situação torna-se problemática na medida em que, em se tratando de teletrabalho, não se sabe qual é efetivamente o local da prestação de serviços, tendo em vista que o trabalho, especialmente no teletrabalho online, é realizado no ciberespaço ${ }^{15}$.

\footnotetext{
${ }^{12}$ Isto é, em uma situação na qual o lugar da prestação de serviços está situado em país diverso do da sede da empresa,

${ }^{13} \mathrm{http}: / /$ www.archivoscen.cenavarra.es/cen/ReformaLaboral2012/13.pdf

${ }^{14}$ Recentemente, o Tribunal Constitucional Espanhol apreciou indagação sobre a constitucionalidade do Real Decreto n³/2012, afastando todas as hipóteses de inconstitucionalidade levantadas (mais atreladas à matriz protetiva e à eventual negação desse caráter em face da flexibilidade contratual propiciada pela norma).
} vol. 08, n. 04, Número Especial. Rio de Janeiro, 2015.pp. 2237-2263 
De acordo com Massani (2005, p. 1215)

La problemática, sin embargo, reside en la dificultad en identificarse el local de la prestación de servicios, visto a su localización virtual. ¿El teletrabajador en domicilio o móvil, que presta servicios online, presta servicios en el local donde reside, en el local de la sede de la empresa para donde envía sus servicios - o en el local de hospedaje del sitio en lo cual está conectado? ¿Si el contrato no posee elección de foro o de ley aplicable, y el empleado fuere teletrabajador móvil, la jurisdicción y el ordenamiento jurídico aplicado pueden ser de cualquier lugar por donde él pasa y presta servicios? ${ }^{16}$

É preciso reinterpretar o local da prestação dos serviços. Manuel Martin Pino Estrada (2002), por exemplo, diz que se deve entender o lugar da prestação dos serviços via interpretação extensiva do lex loci laboris, compreendendo o contexto sui generis do teletrabalho, observando-se a lei do país no qual está sendo recebida a prestação e não onde se encontra fisicamente o teletrabalhador.

José Cairo Junior (2010) comungando deste entendimento explica que, quando o trabalhador estiver conectado (online) com o local de trabalho, tal meio torna-se uma extensão deste centro, como se estivesse trabalhando no próprio local de trabalho (em sua concepção clássica, física, presencial), porque recebe e manuseia o trabalho via ambiente virtual (intranets de acesso remoto e portais, v.g.) e só com a chegada de suas tarefas no local de trabalho, a prestação de serviço estará concluída. Por esta razão, o loci laboris do teletrabalhador seria o lugar onde se encontra localizado o estabelecimento. Como não há regulamentação específica em nível global, seja por meio de um organismo internacional ou por grupos de países, por meio de tratados ou convenções internacionais, a lei aplicável, para o autor e nesse caso, seria a do local do estabelecimento da empresa.

Corroborando da tese da lex loci executionis, Olivares (2005, p. 457) diz que

La principal protección al trabajador ante la ley elegida o la ley del país con conexión más estrecha depende del caso concreto a ser juzgado por el magistrado. Así, se protege el trabajador, hiposuficiente frente al empleador. La conexión más estrecha, el local de prestación de servicios, se muestra de difícil identificación ante a la naturaleza virtual y no física del teletrabajo. La presunción del local de residencia del trabajador será maléfico si el trabajador residir en país menor protector, donde haya peligro del dumping social. La conexión más estrecha, según Guanter y Parra, por lo tanto, es con el país del establecimiento del empleador, pues donde se manifiesta la producción de la prestación de servicios y se unifica las condiciones de trabajo para todos los teletrabajadores de la misma empresa, además de impedir el dumping social. ${ }^{17}$

\footnotetext{
${ }^{15}$ O termo ciberespaço foi idealizado por William Gibson, em 1984, no livro Neuromancer, referindo-se a um espaço virtual composto por cada computador e usuário conectados em uma rede mundial. Fonte: <http://www.infoescola.com/internet/ciberespaco/> Acesso em: 20 mai. 2014.

16 "O problema, porém, reside na dificuldade em identificar o local da prestação de serviços, visto a sua localização virtual. $\mathrm{O}$ teletrabalhador em domicílio ou móvel, que presta serviços online, presta serviços no local onde reside, no local da sede da empresa - para onde envia seus serviços - ou em local de hospedagem do site no qual está conectado? Se o contrato não possui foro de eleição ou de lei aplicável, e o empregado for teletrabalhador móvel, a jurisdição e o ordenamento jurídico aplicado podem ser de qualquer lugar por onde ele passa e presta serviços?”.

17 "A principal proteção ao trabalhador ante a lei eleita ou a lei do país com conexão mais estreita depende do caso concreto a ser julgado pelo magistrado. Assim, se protege o trabalhador, hipossuficiente frente ao empregador. A conexão mais estreita, o local de prestação dos serviços, se mostra de difícil identificação ante a natureza virtual e não física do teletrabalho. A presunção do local de residência do trabalhador será maléfico se o trabalhador residir em país menos protetor, onde haja perigo de dumping social. A conexão mais estreita, segundo Guanter e Parra, portanto, é com o país do estabelecimento do empregador, para onde se manifesta vol. 08, no. 04, Número Especial. Rio de Janeiro, 2015.pp. 2237-2263 2245
} 
O Tribunal Regional do Trabalho da 3a Região, ao julgar a competência e a lei aplicável ao trabalho virtual realizado no Brasil, entendeu pela aplicação das leis brasileiras à relação. Veja-se fragmento do voto:

A transnacionalização do trabalho e a virtualização da prestação dos serviços não dilui os contornos do espaço territorial do solo brasileiro e nem dissolve o vínculo que o empregado tem com a localidade em que se encontra situada a empresa que o emprega, no Brasil. Desta forma a definição da competência territorial da Justiça do Trabalho para a hipótese do trabalhador brasileiro que presta serviços presenciais no exterior e teletrabalho em solo brasileiro, é ditada por interpretação analógica (artigo 8, caput, da CLT) do preceito do art. 651, $\ 1^{\circ}$, da CLT, que estabelece a regra da competência territorial para hipótese do trabalhado externo (prestado por agente ou viajante comercial), fixando-a na localidade em que a empresa tenha agência ou filial no Brasil, à qual esteja subordinado o empregado na execução do contrato de trabalho presencialmente no exterior e em ambiente virtual no Brasil. $^{18}$

Portanto, de acordo com este entendimento, entende-se que o local da prestação de serviços, no teletrabalho, seria o local onde as informações são recebidas, o local onde o produto do trabalho se concretiza, onde há o lucro que motiva a relação capital e trabalho, sendo este local, então, a sede do empregador, definindose com isso qual a lei competente para reger a relação jurídica.

Entretanto, por questões histórico-sociológicas, há no Direito do Trabalho entendimento de que deve ser aplicada a norma mais favorável ao obreiro. Parte desse entendimento a lógica de que ao trabalhador deve ser garantido um mínimo de direitos possíveis, na medida em que o Estado Democrático de Direito ou Estado Social deve assegurar aos trabalhadores uma máxima eficácia de um direito social a prestação, que são os direitos dos trabalhadores (direitos fundamentais sociais, em essência), razão pela qual a Constituição Federal prevê, no caput do art. 70, como norteadora do elenco constante em seus incisos, a "melhoria da condição social dos trabalhadores", o que alça a nível constitucional, o princípio da norma mais favorável ao trabalhador.

Para auxiliar na fundamentação deste entendimento, Nascimento (2005, p.293) invoca o princípio da norma mais favorável insculpida no art. 70, caput, da Constituição Federal, o qual ao estabelecer as diretrizes fundamentais dos direitos dos trabalhadores, o faz como garantias mínimas.

Mauricio Godinho Delgado (2010, p.62) compartilhando da mesma tese diz que o princípio da norma mais favorável encontra-se claramente assumido pela Constituição da República, no Capítulo II do Título II (Dos Direitos e Garantias Fundamentais), isto é, no precitado art. 70, caput.

\footnotetext{
a produção da prestação de serviços e se unifica as condições de trabalho para todos os teletrabalhadores da mesma empresa, ademais de impedir o dumping social".

${ }^{18}$ MINAS GERAIS. Tribunal Regional do Trabalho. Recurso ordinário n. 00435-2010-016-03-00-3, da 3a Turma. Relator: Juiz convocado Milton Vásques Thibau Almeida. Belo Horizonte, 29 de setembro de 2010. Disponível em: <http://www.trt3.jus.br> Acesso em: 10 jun. 2014.
} 
Dallegrave Neto (2000, p. 55) encorpa essa corrente doutrinária, perfilando-se aos demais autores citados quando afirma que, "não é ocioso lembrar que o princípio da norma mais benéfica está estampado no caput do art. $7^{\circ}$ da Constituição Federal”.

Em nível infraconstitucional, tem-se o princípio da norma mais favorável, por exemplo, no art. $3^{\circ}$, II, da Lei $7.064 / 82^{19}$ e no art. $620^{20}$ da CLT.

No direito internacional, encontra-se-o no inciso VIII do art. $19^{21}$ da Constituição da OIT. No México, no art. 18 da Lei Federal do Trabalho, que dispõe: "Na interpretação das normas do trabalho serão consideradas as suas finalidades" e "em caso de dúvida prevalecerá a mais favorável ao trabalhador"22. Na União Europeia, na Diretiva 77/187 sobre transferência de empresas, que declara: "a presente diretiva não prejudica a faculdade dos Estados-membros de aplicar ou introduzir disposições legislativas, regulamentares ou administrativas mais favoráveis aos trabalhadores" (NASCIMENTO, 2005, p.295).

Ainda, merece destaque a norma contida no art. 4º n. 3, do Código do Trabalho de Portugal (Lei 99/2003), pela qual "as normas deste Código só podem ser afastadas por contrato de trabalho quando este estabeleça condições mais favoráveis para o trabalhador e se delas não resultar o contrário" (NASCIMENTO, 2005, p.295).

O princípio da norma mais favorável também é adotado pela Lei do Contrato de Trabalho da Argentina, no art. 9', que proclama: "Em caso de dúvida sobre a aplicação de normas legais ou convencionais, prevalecerá a mais favorável ao trabalhador, considerando-se a norma ou conjunto de normas que discipline cada uma das instituições do direito do trabalho. Se a dúvida recair sobre a interpretação ou o alcance da lei ou na apreciação da prova nos casos concretos, os juízes ou encarregados de aplicá-la decidirão no sentido mais favorável ao trabalhador" (NASCIMENTO, 2005, p.295).

Com base no parágrafo $2^{\circ}$ do art. $5^{\circ}$ da CF/198823 e no inciso VIII do art. 19 da Constituição da OIT, Dallegrave Neto (2000, p. 81-2) diz que a Súmula 207 do TST (hoje cancelada) não passava de uma regra geral,

\footnotetext{
${ }^{19}$ Art. $3^{\circ}$ - A empresa responsável pelo contrato de trabalho do empregado transferido assegurar-lhe-á, independentemente da observância da legislação do local da execução dos serviços:

II a aplicação da legislação brasileira de proteção ao trabalho, naquilo que não for incompatível com o disposto nesta Lei, quando mais favorável do que a legislação territorial, no conjunto de normas e em relação a cada matéria.

${ }^{20}$ Art. 620 - As condições estabelecidas em Convenção, quando mais favoráveis, prevalecerão sobre as estipuladas em Acordo.

${ }^{21}$ Em nenhum caso se poderá considerar que a adoção de uma convenção ou uma recomendação pela Conferência, ou a ratificação de uma convenção por qualquer Membro - refere-se às Convenções e Resoluções da OIT - prejudicará qualquer lei, sentença, costume ou acordo que garanta aos trabalhadores condições mais favoráveis que as que figurem no convênio ou recomendação.

${ }^{22}$ LONGHI, Dânia Fiorin. Teoria do Conglobamento - Conflito de Normas no Contrato de Trabalho. São Paulo: LTr, 2009, p. 68.

${ }^{23}$ Art. $5^{\circ}$ - Todos são iguais perante a lei, sem distinção de qualquer natureza, garantindo-se aos brasileiros e aos estrangeiros residentes no País a inviolabilidade do direito à vida, à liberdade, à igualdade, à segurança e à propriedade, nos termos seguintes: [...] $\S 2^{\circ}$ Os direitos e garantias expressos nesta Constituição não excluem outros decorrentes do regime e dos princípios por ela adotados, ou dos tratados internacionais em que a República Federativa do Brasil seja parte.
} 
advogando a ideia de que se deveria, sempre, primar pela proteção do trabalhador mesmo que contra o critério da territorialidade.

Antonio Galvão Peres (2004, p.115) afirma que

[...] a concepção de que as normas do local de execução devem ser indistintamente aplicáveis aos contratos de trabalho demonstra que a jurisprudência brasileira (Enunciado n. 207) ainda está apegada a um método bilateral clássico, na contramão do direito internacional privado. Preocupa-se com um formalismo exacerbado que reputa favorável ao trabalhador, mas que, na prática, instiga inúmeras desigualdades, afastando-se da justiça material.

A proteção do teletrabalhador em nível transnacional faz-se imperiosa, na medida em que o empregado é hipossuficiente diante do poderio econômico do empregador, sendo evidente a necessidade de aplicação do princípio da norma mais favorável, sustentado pelo art. $7^{\circ}$, caput da $\mathrm{CF} / 1988$ e a aplicação dos princípios internacionais previstos pelo art. $4^{\circ}$, incisos II e IX ${ }^{24}$, também do ordenamento constitucional, como a garantia da eficácia dos direitos humanos trabalhistas.

Arnaldo Süssekind (2000, p.58), apontando para o bom emprego do princípio da norma mais favorável, ensina que:

[...] no campo do direito do trabalho, a solução dos conflitos entre normas internacionais é facilitada pela aplicação do princípio da norma mais favorável aos trabalhadores. Essa regra decorre do próprio caráter desse Direito, que visa a assegurar um mínimo de garantias aos trabalhadores, sendo adequado e conveniente que, entre diversos atos normativos igualmente aplicáveis à relação jurídica em causa, prevaleça o mais benéfico ao trabalhador. Não se trata da inversão da hierarquia das fontes de direito, porquanto é da índole das normas trabalhistas estabelecer um nível de proteção que pode ser superado por outra disposição normativa ou contratual.

A Lei 7.064/82 (trazendo orientação diferente da contida no Código de Bustamante e na antiga redação da Súmula 207 do TST), no seu art. $3^{\circ}$, inciso II, prevê a aplicação da legislação brasileira de proteção ao trabalho naquilo que não for incompatível com o disposto na referida Lei, quando mais favorável do que a legislação territorial, no conjunto de normas e em relação a cada matéria.

Gilda Russomano, citada por Sérgio Martins (2008, p. 121) ensina que "dever-se-ia considerar aplicável à relação jurídica, sobre a qual controvertem duas ou mais de duas leis oriundas de soberanias distintas, aquela que maiores benefícios outorgar ao trabalhador" e Valladão (1978, v.3, p.100), comungando da mesma tese, ensina que se aplica a lei que for mais favorável ao empregado, mesmo que esta seja a estrangeira, visto que concede maiores benefícios ao trabalhador do que a própria legislação brasileira.

Nos tribunais trabalhistas, já há julgados no sentido de aplicação da lei que for mais favorável ao operário. Nesse sentido, é o entendimento, por exemplo, da 8a Turma do Tribunal Regional do Trabalho da 3a Região:

\footnotetext{
${ }^{24}$ Art. $4^{\circ}$ - A República Federativa do Brasil rege-se nas suas relações internacionais pelos seguintes princípios: [...] II prevalência dos direitos humanos [...] IX cooperação entre os povos para o progresso da humanidade
} vol. 08, nº. 04, Número Especial. Rio de Janeiro, 2015.pp. 2237-2263 
PRESTAÇÃO DE SERVIÇOS NO EXTERIOR. APLICAÇÃO DA LEGISLAÇÃO BRASILEIRA MAIS FAVORÁVEL. CONFLITO DE LEIS NO ESPAÇO. Tendo sido o trabalhador contratado no Brasil, por empresa aqui sediada, para trabalhar no exterior, tal fato atrai a incidência da Lei 7.064/82, que assegura ao laborista a aplicação da legislação brasileira protetiva do trabalho, sempre que esta for mais favorável que o disciplinado na lei do local laborativo, afastando o princípio da lex loci executionis contracti, tratado na Súmula 207/TST, de forma genérica, exatamente porque existe lei nacional regulativa específica (7.064/82) disciplinando a hipótese. ${ }^{25}$

Oportuno comentar que a Seção de Dissídios Individuais 1 do Tribunal Superior do Trabalho (SDI-1), há alguns anos, propôs o reexame da Súmula 207 do Tribunal Superior no processo n. E-RR 21900093.2000.5.01.0019. A decisão assegurou os direitos previstos na legislação brasileira a um trabalhador contratado no Brasil e que prestava serviços a subsidiária de empresa nacional no exterior. A relatora, Ministra Maria Cristina Peduzzi, afirmou que o critério da territorialidade, previsto no Código de Bustamante, foi paulatinamente substituído pela aplicação da norma mais favorável ao trabalhador, propondo à Comissão de Jurisprudência a revisão de tal posicionamento. Em abril de 2012 a Súmula foi cancelada.

Nesse diapasão, analisa-se a possibilidade, baseando-se em uma interpretação ampliativa e sistemática, de estender este entendimento, por analogia, à relação jurídica de teletrabalho transnacional, o que se pretende demonstrar nas próximas linhas.

Ressalta-se que, em se tratando de matéria trabalhista, a doutrina clássica aponta que o ápice da hierarquia das fontes deve ser ocupado pela norma que for mais favorável ao obreiro. Esclarece-se que o critério da territorialidade deve ser utilizado como elemento de conexão para solução dos conflitos de leis no espaço somente como regra geral. A doutrina e a jurisprudência, bem como a previsão em norma infraconstitucional, no direito internacional e na própria Constituição Federal de 1988, além da necessária proteção do hipossuficiente, constituem os fundamentos para robustecer a tese que faz prevalecer o princípio da norma mais favorável e, assim, garantir a eficácia dos direitos fundamentais dos trabalhadores nas relações de prestação de serviços transnacionais.

\section{O CIBERESPAÇO COMO LOCAL DE TRABALHO}

Inicialmente, cumpre ressaltar que o local da prestação dos serviços no teletrabalho é, rotineiramente, o ciberespaço (isto é, um local não físico). Ao se observar o sentido clássico de local como elemento atrelado a limites geográficos, pode-se dizer que o teletrabalho é exemplo de trabalho desterritorializado. A partir disto, é relevante estudar o ciberespaço, especialmente quando se pretende defini-lo como local da efetiva prestação laboral, para os efeitos dessa investigação.

\footnotetext{
${ }^{25}$ MINAS GERAIS. Tribunal Regional do Trabalho. Recurso ordinário n. 0000869-26.2010.5.03.0091, da 8a Turma. Relator: Desembargador Márcio Ribeiro do Valle. Belo Horizonte, 16 de fevereiro de 2011. Disponível em: <http://www.trt3.jus.br> Acesso em: 10 jun. 2012.
} 
Joan Mayans (2002, p.33) ${ }^{26}$ conceitua ciberespaço como:

[... ] un tipo de espacio social creado de forma artificial, informáticamente, basado en flujos de información (cibernéticos) en formato digital, que es experimentada por los usuarios de forma híbrida o ciborg, es decir, a través de una mezcla de su cuerpo físico (orgánico) y de las diferentes máquinas y tecnologías que lo llevan allí. El ciberespacio, o, hablando con más propiedad, los ciberespacios a los que nos estamos refiriendo, son pues, los entornos interactivos y multipersonales utilizados (habitados) y creados por los usuarios de las diversas tecnologías que permiten la interconexión entre ordenadores o similares.

Também relevante a lição de Jorge Alberto Machado (2002, p.35):

[...] o ciberespaço é um espaço não-material e não configurado geograficamente. Composto por redes de computadores, telecomunicações, programas, interfaces e banco de dados onde a experiência humana passa a existir sob a forma de bits. $O$ ciberespaço seria uma projeção da realidade, que só existe virtualmente dentro de tais redes, onde os signos da experiência humana se convertem em pixels (contração de picture element) na tela do computador.

O teletrabalho é modalidade de trabalho, a partir da qual alguém presta serviços por meio das

ferramentas de comunicação e informação (notoriamente internet), distante geograficamente de seu tomador de serviços. Nesse sentido, argumenta Olivares (2005, p.419) 27:

Como se avanzó, las nuevas tecnologías de la información están permitiendo que el trabajo basado en la información (creación, tratamiento o procesamiento) pueda ejecutarse en cualquier lugar, de suerte que el trabajo está abandonando los lugares de producción habituales, produciéndose una deslocalización de las atividades productivas y, por ende, una flexibilización sin precedentes del lugar de trabajo.

Esse novo formato da sociedade contemporânea propiciado pelas novas tecnologias, portanto, deslocou

a realização das atividades laborativas do estabelecimento do empregador para qualquer lugar do mundo (inclusive para um "não-lugar"), flexibilizando sobremaneira o local da prestação de serviços.

Pierre Lévy (1996, p. 17-8), marco teórico obrigatório, ao se tratar da virtualização das relações ou de seu deslocamento para esse espaço denominado ciber (ou cyber), explica que

A virtualização pode ser definida como o movimento inverso da atualização. Consiste em uma passagem do atual ao virtual, em uma "elevação à potência" da entidade considerada. A virtualização não é uma desrealização (a transformação de uma realidade num conjunto de possíveis), mas uma mutação de identidade, um deslocamento do centro de gravidade ontológico do objeto considerado: em vez de se definir principalmente por sua atualidade (uma "solução"), a entidade passa a encontrar sua consistência essencial num campo problemático.

Pode-se desde logo concluir que o virtual é real, só não é físico. Verifica-se, que quando ocorre a virtualização de uma solução gera-se um outro problema, transformando a atualidade inicial em caso particular de

\footnotetext{
26 "Um tipo de espaço social criado de forma artificial, informaticamente, baseado em fluxos de informação (cibernéticos) em formato digital, que é experimentada pelo usuários de forma híbrida ou ciborg, é dizer, através de uma mescla de seu corpo físico (orgânico) e das diferentes máquinas e tecnologias que o levam ali. O ciberespaço, ou, falando com mais propriedade, os ciberespaços aos quais estamos nos referindo, são, pois, os entornos interativos e multipessoais utilizados (habitados) e criados pelos usuários das diversas tecnologias que permitem a interconexão entre ordenadores ou similares”.

27 "Como se avançou, as novas tecnologias da informação estão permitindo que o trabalho baseado na informação (criação, tratamento ou processamento) possa executar-se em qualquer lugar, de sorte que o trabalho está abandonando os lugares de produção habituais, produzindo-se um deslocamento das atividades produtivas e, por consequência, uma flexibilização sem precedentes do lugar de trabalho".
} 
uma problemática mais geral. Segundo Lévy (1996, p.18), "a virtualização é um dos principais vetores da criação de realidade".

O que não se pode negar é que a internet facilitou (e muito) as relações interpessoais, possibilitando, por meio da relativização do espaço geográfico tradicional, a transformação e/ou o surgimento de várias relações, sem a compulsória presença física das pessoas, levando à consolidação do teletrabalho, que é realizado à distância, com a mediação das tecnologias de comunicação e informação, sem a necessidade de o empregado comparecer fisicamente à sede da empresa.

Veja-se o que retrata Lévy (1996, p.18):

Tomemos o caso, muito contemporâneo, da "virtualização" de uma empresa. A organização clássica reúne seus empregados no mesmo prédio ou num conjunto de departamentos. Cada empregado ocupa um posto de trabalho precisamente situado e seu livro de ponto especifica os horários de trabalho. Uma empresa virtual, em troca, serve-se principalmente do teletrabalho; tende a substituir a presença física de seus empregados nos mesmos locais pela participação numa rede de comunicação eletrônica e pelo uso de recursos e programas que favoreçam a cooperação. Assim, a virtualização da empresa consiste sobretudo em fazer das coordenadas espaço-temporais do trabalho um problema sempre repensado e não uma solução estável. $\mathrm{O}$ centro de gravidade da organização não é mais um conjunto de departamentos, de postos de trabalho e de livros de ponto, mas um processo de coordenação que redistribui sempre diferentemente as coordenadas espaço-temporais da coletividade de trabalho e de cada um de seus membros em função de diversas exigências.

O trabalho à distância desterritorializa a prestação de serviços e mitiga a subordinação tradicional do trabalhador, criando novos paradigmas para a ciência jurídica.

O Direito, tradicionalmente, tem sua aplicação observando-se o espaço e o tempo em que ocorrentes os fatos. Especialmente quanto ao espaço é que se tem necessárias redefinições juscientíficas. Nessa linha de raciocínio, discorre Pinheiro (2009, p.39):

[...] na Internet, muitas vezes não é possível reconhecer facilmente de onde o interlocutor está interagindo. Muitos sites têm terminação ".com", sem o sufixo de país (por exemplo, sem o "br" em seguida) o que teoricamente significa que estão localizados nos Estados Unidos. Só que vários deles apenas estão registrados nos Estados Unidos e não tem nenhuma [correspondência de] existência física nesse país. Uma tendência mundial é assumir definitivamente o endereço eletrônico como localização da origem ou efeito do ato. Assim, se uma empresa brasileira registra um site como ".com", em vez de ".com.br", pode ter de se sujeitar às leis de diversos países no caso de questões jurídicas internacionais.

Da mesma forma, é o raciocínio de Renato Opice Blum (2001, p.38):

As relações virtuais e seus efeitos são realidade. A tendência é a substituição gradativa do meio físico pelo virtual ou eletrônico, o que já ocorre e justifica a adequação, adaptação e interpretação das normas jurídicas nesse novo ambiente. Na grande maioria dos casos é possível a aplicação das leis já existentes, o que gera direitos e deveres que deverão ser exercidos e respeitados. Assim, de rigor, é imprescindível o estudo, orientação e aplicação da Internet como ambiente de resultados legais sérios e com enorme potencial de efeitos jurídicos, como, por exemplo, a possibilidade, desde já, da assinatura digital de contratos eletrônicos entre as partes com segurança muitas vezes superior àquela utilizada no meio físico. 
No teletrabalho, especialmente na modalidade "online", o lugar da prestação dos serviços não tem natureza física, porém, sua natureza virtual é igualmente real e, portanto, geradora de efeitos. Nesse sentido, explica Octavio Ianni (2002, p.95):

Assim se desenvolve o novo e surpreendente processo de desterritorialização, uma característica essencial da sociedade global em formação. Formam-se estruturas de poder econômico, político, social e cultural internacionais, mundiais ou globais descentradas, sem qualquer localização nítida neste ou naquele lugar, região ou nação. Estão presentes em muitos lugares, nações, continentes, parecendo flutuar por sobre Estados e fronteiras, moedas e línguas, grupos e classes, movimentos sociais e partidos políticos.

Pode-se dizer que a desterritorialização relativiza a aplicação do direito no espaço, na medida em que não se está diante de um local de prestação de serviços tradicional.

A situação torna-se problemática na medida em que, em se tratando de teletrabalho, pode não se ter precisão (real ou conceitual) de qual é efetivamente o local da prestação de serviços, com o fito de definir um elemento de conexão apto a solucionar o conflito de leis trabalhistas.

Silvana Drumond Monteiro (2007) afirma que o ciberespaço é um ambiente que nos permite inúmeras possibilidades de mundo "real". É um ambiente onde pessoas do mundo todo podem interagir sem estar, de fato, fisicamente presentes. É um novo espaço de comunicação, representação, construção de identidades e interação. O termo ciberespaço, em sua etimologia, já nos propõe essa nova noção: cyber + espaço, ou seja, um espaço diferente, cibernético, com novas possibilidades e implicações.

Ao aceitar que o virtual é real, surgem outros problemas, derivados segundo Lévy (1996, p.18), "da [re]criação de realidade".

Nesse diapasão, o ciberespaço possibilita, por exemplo, a transmissão ou comunhão de dados e informações de forma instantânea e eficaz ou a interação entre pessoas de modo não físico, mas síncrono.

Com efeito, Lévy (1999, p. 94-5) conceitua o ciberespaço como:

[...] o espaço de comunicação aberto pela interconexão mundial dos computadores e das memórias dos computadores. Essa definição inclui o conjunto dos sistemas de comunicação eletrônicos (aí incluídos os conjuntos de redes hertzianas e telefônicas clássicas), na medida em que transmitem informações provenientes de fontes digitais ou destinadas à digitalização.

De acordo com os ensinamentos de Lucia Santaella (2004, p. 40-1) o ciberespaço deve ser concebido como um mundo virtual global coerente, independente de como se acede a ele e como se navega nele. Tal qual uma língua, cuja consistência interna não depende de que os seus falantes estejam, de fato, pronunciando-a, independe das configurações específicas que um usuário particular consegue extrair dele.

No seu sentido mais amplo, o ciberespaço refere-se a um sistema de comunicação eletrônica global que reúne os humanos e os computadores em uma relação simbiótica que cresce exponencialmente graças à comunicação interativa. Trata-se, portanto, de um espaço informacional, no qual os dados são configurados de tal 
modo que o usuário pode acessar, movimentar-se e trocar informações com um incontável número de outros usuários (SANTAELLA, 2004, p.45).

Por fim, novamente emprestando os ensinamentos de Lucia Santaella (2004, p. 45):

O ciberespaço será considerado como todo e qualquer espaço informacional multidimensional que, dependente da interação do usuário, permite a este o acesso, a manipulação, a transformação e o intercâmbio de seus fluxos codificados de informação. Assim sendo, o ciberespaço é o espaço que se abre quando o usuário conecta-se com a rede. Por isso mesmo, esse espaço também inclui os usuários dos aparelhos sem fio, na medida em que esses aparelhos permitem a conexão e troca de informações. Conclusão, ciberespaço é um espaço feito de circuitos informacionais navegáveis. Um mundo virtual da comunicação informática, um universo etéreo que se expande indefinidamente mais além da tela, por menor que esta seja, podendo caber até mesmo na palma de nossa mão.

Percebe-se, desse modo, que o ciberespaço é um mundo virtual, capaz de envolver todas as informações existentes no planeta, interagidas pelo usuário. É possível, por meio do ciberespaço, comunicar e trocar informações com um número indeterminado de usuários, de e para qualquer lugar do mundo.

Analisando a questão do Direito e do ciberespaço, afirmam David R. Johnson e David G. Post (1996, p. $1367)^{28}$

Global computer-based communications cut across territorial borders, creating a new realm of human activity and undermining the feasibility--and legitimacy--of applying laws based on geographic boundaries. While these electronic communications play havoc with geographic boundaries, a new boundary, made up of the screens and passwords that separate the virtual world from the real world of atoms, emerges. This new boundary defines a distinct Cyberspace that needs and can create new law and legal institutions of its own. Territoriallybased law-making and law-enforcing authorities find this new environment deeply threatening. But established territorial authorities may yet learn to defer to the self-regulatory efforts of Cyberspace participants who care most deeply about this new digital trade in ideas, information, and services. Separated from doctrine tied to territorial jurisdictions, new rules will emerge, in a variety of on-line spaces, to govern a wide range of new phenomena that have no clear parallel in the nonvirtual world. These new rules will play the role of law by defining legal personhood and property, resolving disputes, and crystallizing a collective conversation about core values.

Sobre o que é o virtual, convém ainda destacar os ensinamentos de Rob Shields (2003, p.2) ${ }^{29}$ :

\footnotetext{
${ }^{28}$ Em livre versão: "Comunicações baseadas em computadores globais atravessam fronteiras territoriais, criando um novo campo de atividade humana e minando a viabilidade e legitimidade para aplicar a legislação com base em limites geográficos. Enquanto essas comunicações eletrônicas devastam com as fronteiras geográficas, uma nova fronteira, constituída de telas e senhas que separam o mundo virtual do mundo real de átomos, emerge. Este novo limite define um distinto ciberespaço que precisa e pode criar nova lei e instituições jurídicas próprias. Autoridades que legislam sobre base territorial e as que aplicam a lei encontram este novo ambiente profundamente ameaçador. Mas as autoridades territoriais estabelecidas ainda podem aprender a adiar para os esforços de auto-regulação dos participantes do ciberespaço que se importam mais profundamente sobre este novo comércio digital em ideias, informações e serviços. Separado da doutrina ligada a jurisdições territoriais, novas regras surgirão, em uma variedade de espaços on-line, para governar uma ampla gama de um novo fenômeno que não tem claro paralelo no mundo não virtual. Estas novas regras desempenharão o papel da lei, definindo personalidade jurídica e propriedade, solucionando conflitos, e cristalizando uma conversa coletiva sobre valores fundamentais".

${ }^{29}$ Em livre versão: "Os dicionários definem o virtual na vida cotidiana como 'aquilo que é tão em essência mas não tanto assim'. Assim, falamos de tarefas que são 'virtualmente completas'. Mais filosoficamente, o virtual capta a natureza das atividades e objetos que existem, mas não são tangíveis, não são 'concretos'. O virtual é real, mas não concreto [...]. O substantivo 'virtual' vem a nós do latim virtus, tornou-se virtualis e foi entendido de maneira que possamos entender a palavra "virtude" hoje. Neste uso mais antigo, vol. 08, n. 04, Número Especial. Rio de Janeiro, 2015.pp. 2237-2263 
Dictionaries define the virtual in everyday life as 'that which is so in essence but not actually so'. Thus we speak of tasks which are 'virtually complete'. More philosophically, the virtual captures the nature of activities and objects which exist but are not tangible, not 'concrete'. The virtual is real but not concrete. [... The noun 'virtual' comes to us from the Latin virtus, had become virtualis and was understood in the manner we might understand the word 'virtue' today. In this older usage, a 'virtual person'is what we might understand in more contemporary usage as a person of some outstanding quality.

Em contribuição ao tema, ainda ensina Hardt $\left(1993\right.$, P.16) ${ }^{30}$

The possible is never real, even though it may be actual; however, while the virtual may not be actual, it is none the less real. In other words, there are several contemporary (actual) possibilities of which some may be realized in the future; in contrast, virtualities are always real (in the past, in memory) and may become actualized in the present.

Neste contexto, já não há mais receio em afirmar que o mundo virtual é um mundo real, devendo o direito regulamentar os desdobramentos ocorridos nesse meio.

Vislumbra-se o ciberespaço como o principal canal de comunicação e suporte da informação da humanidade para os próximos séculos (LÉVY, 1999, p.95), o que implica a necessária ressignificação dos conceitos de território, soberania e cidadania (MACHADO, 2002, p. 35-6).

Com efeito, é necessário fazer uma releitura do que se entende por meio ambiente do trabalho, especialmente à luz do fenômeno do teletrabalho, sobretudo, quando transnacional. A ideia clássica de meio ambiente de trabalho (complexo de máquinas, edificações e trabalho) não se sustenta diante da crescente utilização das tecnologias pelos trabalhadores para a prestação dos serviços. Isso porque o ambiente de trabalho é ampliado para além dos estabelecimentos físicos das fábricas e escritórios (2014, p. 441-2).

Assim, levando-se em consideração esse local virtual de prestação dos serviços, Francisco Milton Araújo Júnior (2014, p. 442-3) remete-nos à ideia de liquidez nas relações e fluidez nos espaços em que tais relações ocorrem. Para o autor mencionado, o local da prestação de serviços, no teletrabalho, pode ser, sem dúvida alguma, o ciberespaço. Por outro lado, há uma parte da doutrina que entende o local da prestação de serviços como aquele onde se está produzindo a riqueza, o lucro, normalmente o local do estabelecimento da empresa. Nesse sentido, tem-se comprovada a necessidade de uma reinterpretação do conceito do local da prestação dos serviços. Segundo os ensinamentos de Manuel Martin Pino Estrada(2002), entende-se por lei do lugar da prestação dos serviços, por uma interpretação extensiva do lex loci laboris, em contexto de teletrabalho, a lei do país no qual está sendo recebida a prestação, e não onde se encontra fisicamente o teletrabalhador.

José Cairo Junior (2012), comungando deste entendimento, explica que, quando o trabalhador estiver conectado, online, com o local de trabalho, o computador de onde trabalha será uma extensão deste centro, como

uma 'pessoa virtual' é o que nós devemos entender no uso mais contemporâneo como uma pessoa de alguma qualidade excepcional".

${ }^{30}$ Em livre versão: "O possível nunca é real, mesmo que possa ser atual; no entanto, enquanto o virtual possa não ser atual, ele não é menos real. Em outras palavras, existem várias possibilidades contemporâneas (atuais), das quais algumas possam ser realizadas no futuro; em contraste, virtualidades são sempre reais (no passado, em memória) e podem tornar-se atualizadas no presente". vol. 08, nº. 04, Número Especial. Rio de Janeiro, 2015.pp. 2237-2263 
se estivesse trabalhando lá, porque só com a chegada de suas tarefas no local de trabalho, a prestação de serviço estará concluída. Por esta razão, o loci laboris do teletrabalhador seria o lugar onde se encontra localizado o estabelecimento. Como não há regulamentação específica em nível global, seja por meio de um organismo internacional ou por grupos de países, por meio de tratados ou convenções internacionais, a lei aplicável seria a do local do estabelecimento da empresa.

Portanto, entende-se necessário saber onde se dá a prestação de serviços a fim de definir este local como o elemento de conexão atinente ao critério da territorialidade. Definidos os elementos de conexão aplicáveis à relação jurídica, resta saber qual ordenamento será o efetivamente aplicado.

No teletrabalho transnacional, é imperiosa a reinterpretação do local da prestação dos serviços em face da virtualidade na prestação da atividade laboral. Esse local pode ser estendido àquele para onde as informações são enviadas, isto é, o local onde está fisicamente estabelecido o empregador. Pode também ser aquele em que o teletrabalhador se encontra fisicamente (seu domićlio, por exemplo - salvo no teletrabalho móvel), ou ainda, pode ser o local onde está situado o provedor da internet utilizada como canal de comunicação na relação laboral.

Definidos os elementos de conexão mais estreitamente aplicáveis à relação jurídica de teletrabalho transnacional, cumpre verificar qual critério deve ser o escolhido para reger a relação jurídica.

Dentre os diversos elementos aplicáveis, mencionados nesse estudo, elege-se o da norma mais favorável ao trabalhador. Tendo em vista que aplicar a norma mais favorável ao trabalhador pode levar a discrepâncias entre trabalhadores que estão no mesmo espaço físico-geográfico, pode-se ter problemas com o princípio da igualdade. Assim, passa-se a analisar uma possível colisão de direitos fundamentais (proteção - norma mais favorável - e igualdade).

Parte-se da premissa já explorada neste artigo de que o critério da territorialidade não é suficiente para reger uma relação de teletrabalho transnacional, eis que a prestação de serviços não se dá em um território, no sentido clássico e estrito.

\section{COLISÃO DE PRINCÍPIOS FUNDAMENTAIS: IGUALDADE X NORMA MAIS FAVORÁVEL?}

Como já mencionado anteriormente, na relação jurídica de teletrabalho transnacional, é possível existir dúvida acerca da lei aplicável ao contrato. Os elementos de conexão eleitos pelo direito do trabalho e mais estreitos à relação jurídica laboral, para solucionar a questão da lei aplicável, constituem-se em verdadeiros princípios: o da igualdade por meio do critério da territorialidade e o da norma mais favorável. Dessa forma, é possível ocorrer uma colisão entre esses valores no caso concreto, razão pela qual se exige uma tarefa exegética do intérprete, o que adiante será demonstrado. 
Os elementos de conexão existentes para solucionar o conflito de leis no espaço na hipótese de teletrabalho transnacional, principalmente, são o princípio da igualdade e o da norma mais favorável, sendo possível a aplicação concomitante desses dois valores no caso concreto, na medida em que ambos podem ser aplicados à solução do problema da aplicação das leis no espaço, restando saber se da concomitância surge colidência.

Com efeito, será possível a aplicação dos dois princípios: igualdade (utilizando a territorialidade como critério para a definição da lei aplicável ao teletrabalho transnacional) e proteção (via subprincípio da norma mais favorável, que não parte da igualdade em si, mas da ideia de melhoria da condição social do trabalhador como valor e instituto jurídico). Esses dois princípios serão analisados no caso concreto, devendo prevalecer um deles, mediante o critério da ponderação. Dessa forma, justifica-se a hierarquização axiológica dos princípios, na medida em que se tem valores fundamentais colidentes.

Objetiva-se, assim, encontrar uma solução adequada, ponderando, no caso concreto, o princípio de maior peso, sem necessariamente excluir a aplicação daquele de menor peso. Propõe-se uma solução de acordo com os ditames da justiça social, pautada nos valores da igualdade ou da norma mais favorável ao trabalhador, dependendo do caso concreto. Como se trata de uma relação trabalhista, prima-se pela máxima eficácia possível, notadamente ao art. $7^{\circ}$ da CF, para garantir a concretização do princípio da dignidade da pessoa humana e a efetividade dos direitos humanos trabalhistas em nível universal. Assim, o princípio da igualdade não deixará de ser aplicado em detrimento do princípio da norma mais favorável e vice-versa. Na verdade, considerando o sistema jurídico e de acordo com Juarez Freitas (2010, p.63),

[...] uma rede axiológica e hierarquizada topicamente de princípios fundamentais, de normas estritas (ou regras) e de valores jurídicos cuja função é a de, evitando ou superando antinomias em sentido amplo, dar cumprimento aos objetivos justificadores do Estado Democrático, assim como se encontram consubstanciados, expressa ou implicitamente, na Constituição.

Constata-se o risco de uma colisão de direitos ou princípios fundamentais. Nesse sentido, Canotilho (2000, p. 1229) afirma que:

[...] há uma colisão autêntica de direitos fundamentais quando o exercício de um direito fundamental por parte do seu titular colide com o exercício do direito fundamental por parte de outro titular, ocorrendo um verdadeiro choque ou conflito de direitos.

Assim, no caso concreto, o intérprete fará uma análise de ponderação dos valores em suposto conflito, decidindo, em cada caso, qual dos valores prevalecerá, razão pela qual se faz imprescindível trazer à baila as teorias de Robert Alexy e Ronald Dworkin, ainda que de forma perfunctória.

Ronald Dworkin (2002, p. 39) afirma que os princípios se diferenciam das regras por meio de uma distinção lógica, na qual estas são aplicadas em um critério do "tudo ou nada" (all-or-nothing). Segundo o autor, os princípios possuem uma dimensão do peso ou importância. Assim, na colisão de regras, uma cederá espaço à 
outra, enquanto que, na colisão entre princípios, deverão ser analisados os pesos de cada um, harmonizando-se sua convivência (DWORKIN, 2002, p. 42-3).

Já a doutrina de Robert Alexy (2012, p.90) revela uma pequena diferença com relação ao entendimento de Dworkin, no que tange à aplicabilidade dos princípios, reconhecendo que princípios e regras são espécies do gênero norma (ALEXY, 2012, p.87). Segundo o autor, "o ponto decisivo na distinção entre regras e princípios é que princípios são normas que ordenam que algo seja realizado na maior medida possível dentro das possibilidades jurídicas e fáticas existentes". Alexy (2012, p.90) ensina que os princípios são mandamentos de otimização, caracterizados pela possibilidade de satisfação em graus variados e pelo fato de que sua satisfação não está atrelada apenas às variáveis fáticas, mas também e principalmente às variáveis jurídicas (princípios e regras eventualmente colidentes).E, nessa linha de raciocínio, o autor distingue as regras dos princípios com base nos critérios de solução de conflitos entre princípios e regras. Segundo Alexy (2012, p.92), um conflito de regras somente pode ser resolvido com a declaração de invalidade de uma das regras (extirpando-se-a do ordenamento jurídico) ou com a introdução, em uma destas, de uma clausula de exceção de aplicabilidade.

Por outro lado, com relação à colisão entre princípios, Alexy (2012, p. 93) propõe solução distinta:

Se dois princípios colidem - o que ocorre, por exemplo, quando algo é proibido de acordo com um princípio e, de acordo com o outro, permitido -, um dos princípios terá que ceder. Isso não significa, contudo, nem que o princípio cedente deva ser declarado inválido, nem que nele deverá ser introduzida uma cláusula de exceção. (grifou-se)

Acrescenta o autor que o "conflito" deve, ao contrário, ser resolvido "por meio de um sopesamento entre os interesses conflitantes". O objetivo desse sopesamento é definir qual dos interesses - que abstratamente estão no mesmo nível - tem maior peso no caso concreto" (ALEXY, 2012, p.95).

Portanto, aferir-se-á, no caso concreto, qual dos princípios possui maior peso, e que prevalecerá, o que se opera no plano valorativo (dimensão do peso), diferentemente das regras, em que se operará no plano da validade (ALEXY, 2012, p. 94).

Dessa forma, pode-se aplicar a teoria de Alexy na colisão de direitos fundamentais. Enquanto a aplicação das regras se opera na dimensão do "tudo ou nada", os princípios são hierarquicamente iguais, sendo hipoteticamente possível a colisão somente no caso concreto, devendo o intérprete fazer a ponderação dos valores em suposto conflito, avaliando o peso de cada princípio, fazendo concessões recíprocas, e não excluindo um em detrimento do outro (BARROSO, 2007, p. 66).

Juarez Freitas (2010, p. 229-30) leciona que todos os princípios devem ser preservados e que a antinomia de princípios deve ser solucionada pela hierarquização axiológica, mencionando que isso se identifica com a ponderação e que a antinomia entre regras será resolvida igualmente pela prevalência de determinado princípio no caso concreto. Diante desses ensinamentos, percebe-se, pois, que a diferença entre princípios e regras, na verdade, trata-se de uma diferença hierárquica, e não de qualidade. 
Quanto ao critério da ponderação, Barroso (2007, p. 72-3) ensina que consiste em uma técnica de decisão jurídica aplicável aos casos difíceis (hard cases), quando uma específica situação enseja a aplicação de normas de mesma hierarquia com soluções diferenciadas. Segundo o autor, a ponderação é descrita em três etapas: na primeira, o intérprete deve detectar no sistema as normas para a solução do caso, identificando eventuais conflitos entre elas; na segunda, os fatos devem ser examinados, as circunstâncias concretas do caso e sua interação com os elementos normativos; e, na última etapa, os diferentes grupos de normas e a repercussão dos fatos do caso concreto serão examinados de forma conjunta, de forma a apurar os pesos a serem atribuídos aos diversos elementos em disputa e, dessa forma, o grupo de normas a preponderar no caso concreto. Depois disso, aponta o autor que:

[...] é preciso ainda decidir quão intensamente esse grupo de normas - e a solução por ele indicada - deve prevalecer em detrimento dos demais, isto é: sendo possível graduar a intensidade da solução escolhida, cabe ainda decidir qual deve ser o grau apropriado em que a solução deve ser aplicada. Todo esse processo intelectual tem como fio condutor o princípio instrumental da proporcionalidade ou razoabilidade. (BARROSO, 2007, p. 73)

O critério hermenêutico de ponderação dos valores é definido, por Alexy, como uma máxima de proporcionalidade, a qual é composta de três máximas parciais: a adequação (relação entre o meio empregado e o fim atingido), a necessidade (a norma aplicada deve considerar o meio mais benéfico) e a proporcionalidade em sentido estrito (ponderação dos valores fundamentais). Segundo o autor, as máximas de adequação e de necessidade levam em consideração as possibilidades fáticas decorrentes do caso concreto, ao passo que a proporcionalidade em sentido estrito considera as possibilidades jurídicas. Após este procedimento, afirma ser possível definir o princípio prevalente (ALEXY, 2012, p. 116-7).

\section{CONCLUSÃO}

A partir do que foi visto, verifica-se que o conflito entre o princípio da igualdade e o princípio da norma mais favorável não traduz uma antinomia de regras, razão pela qual não será possível responder se, no caso concreto, acerca da relação de teletrabalho transnacional, a igualdade entre os empregados de uma mesma empresa e de um mesmo território suprime a aplicação da norma que for mais favorável ao teletrabalhador, ou (considerando que a norma mais favorável ao obreiro é princípio que norteia o direito do trabalho e deve prevalecer como uma forma de eficácia dos direitos humanos trabalhistas e, por isso, plenamente oponível na relação de emprego) se prejudicada estará a aplicação de normas iguais aos trabalhadores de uma mesma empresa e/ou território. Isso porque não se está na dimensão do "tudo ou nada" em que a adoção de uma regra importa a exclusão da outra.

Observando-se o objeto desse estudo, constata-se um choque entre princípios e não meramente entre normas. Para solucionar o conflito de leis no espaço na relação jurídica de teletrabalho transnacional, tem-se a 
possibilidade, de um lado, de aplicar a lei que for mais favorável ao trabalhador (o que traduz o princípio da proteção) ou a lei que se aplica aos trabalhadores que laboram fisicamente na sede da empresa (traduzindo o princípio da igualdade). Parte-se do suposto trazido por Freitas (2004, p.39) de que um direito não deve suprimir inteiramente o outro na colisão, eis que os princípios nunca se eliminam (diferentemente do que ocorre nas antinomias normativas). A harmonização, via ponderação, é o grande desafio do jurista. Assim, a análise do problema deve ser operada no plano valorativo, levando em conta, conforme Alexy (2012, p.94), o "peso" dos princípios em conflito.

A partir disso, verifica-se que o problema abordado no presente trabalho tem como fio condutor, conforme referido por Luís Roberto Barroso (2007, p.73), o princípio instrumental da proporcionalidade ou razoabilidade. Segundo Paulo Bonavides (2004, p. 425), referido princípio pode ser aplicado como instrumento de interpretação toda vez que ocorre antagonismo entre direitos fundamentais e se busca uma solução apropriada para diminuir ou eliminar a colisão de tais direitos.

Nesse diapasão, o princípio da proporcionalidade manifesta-se por meio de três subprincípios: adequação, necessidade e proporcionalidade em sentido estrito. Com relação ao primeiro, deve verificar se o meio adotado é adequado para alcançar o fim almejado. No que concerne à necessidade, no caso de mais de um meio idôneo, deve ser escolhido aquele que seja menos gravoso ao exercício do direito fundamental (TEIXEIRA, 2005, p. 137). E, por fim, a proporcionalidade em sentido estrito, que consiste na valoração entre a restrição ao direito fundamental atingido e a importância da realização do direito fundamental que com ele colide e que fundamenta a adoção da medida restritiva (SILVA, 2002, p. 40).

Portanto, a partir do princípio da proporcionalidade, é possível advogar pela aplicabilidade da norma mais favorável ao teletrabalhador dentre as incidentes à relação jurídica. Com base na adequação, necessidade e proporcionalidade em sentido estrito, poder-se-á concluir que, em alguns casos, o princípio da igualdade possui peso menor que o da norma mais favorável, como, por exemplo, no caso de trabalho realizado em países com direitos trabalhistas mínimos, sendo terreno fértil para a ocorrência de dumping social. Nesse caso, opina-se pela não aplicação ao teletrabalhador da mesma norma que se aplica aos demais trabalhadores da mesma empresa ou àqueles que laboram no mesmo território, e sim, da norma que for mais favorável, no seu conjunto, ao teletrabalhador, podendo ser a lei do país de origem do obreiro (por exemplo, se for brasileiro, a lei trabalhista brasileira).

Em outras situações, no caso de prestação de serviço em territórios com leis mais protecionistas ao trabalhador, deve prevalecer o princípio da igualdade, aplicando-se a lei do local da prestação dos serviços que também é aplicada aos demais trabalhadores da empresa. O intérprete deverá, no caso concreto, atender ao critério de proporcionalidade, prevalecendo maior carga de um princípio, em detrimento do outro, de acordo 
com as circunstâncias específicas do caso concreto, o que se fará mediante o emprego do critério da ponderação, já que a antinomia de princípios é resolvida no plano da hierarquização axiológica.

\title{
CYBER AS WORKPLACE: THE PROBLEM (OR SOLUTION?) OF TRANSNATIONAL TELEWORKING
}

\begin{abstract}
Analyzes the situation of the transnational teleworkers, especially focusing on the law to be applied to the transaction. It starts with the premise that the workspace, teleworking, is a virtual place called cyberspace, making it therefore difficult to apply the territorial connection element to the international contract, generating the studied problem. The principle of a more lenient standard initially consider to be most appropriate. However, you must test whether their application would not generate violation of the principle of equality. It concludes by applying the weighting, suggesting Resolution series, in which can be applied to standard nationality of the telecommuter or the norm of where it provides its services, always seeking protection and social progress, coupled with the prevention of dumping social.
\end{abstract}

Keywords: Telework Transnational. Applicable standard. Protection. Social dumping.

\section{REFERENCIAS}

ALEXY, Robert. Teoria dos direitos fundamentais. São Paulo: Malheiros, 2012.

AMORIM, Edgar Carlos. Direito Internacional Privado. Rio de Janeiro: Forense, 2002.

ARAÚJO JUNIOR, Francisco Milton. Parâmetros para delimitação do meio ambiente do trabalho na volatilidade da sociedade contemporânea (ciberespaço). Revista LTr, São Paulo: LTr, ano 78, n. 4, abr. 2014.

ARAUJO, Nadia de. Contratos internacionais: autonomia da vontade, Mercosul e convenções internacionais. Rio de Janeiro: Renovar, 2004.

Direito Internacional Privado. Rio de Janeiro: Renovar, 2006.

BARROSO, Luís Roberto. Liberdade de expressão versus direitos da personalidade. Colisão de direitos fundamentais e critérios de ponderação. In: SARLET, Ingo Wolfgang (Org.). Direitos Fundamentais, Informática e Comunicação: algumas aproximações. Porto Alegre: Livraria do Advogado, 2007.

BLUM, Renato M. S. Opice. O processo eletrônico: assinaturas, provas, documentos e instrumentos digitais. In: (Coord.). Direito eletrônico: a Internet e os tribunais. Bauru: EDIPRO, 2001.

BONAVIDES, Paulo. Curso de direito constitucional. São Paulo: Malheiros, 2004. 
CAIRO JUNIOR, José. (2010). O local de trabalho virtual como critério definidor da vigência da lei no espaço nas relações de teletrabalho. Disponível em: <http://www.amatra5.org.br/amatra5/noticia_sem_imagem.jsp?id=399> Acesso em: 15 jul. 2012.

CANOTILHO,J.J. Gomes. Direito constitucional e teoria da constituição. Coimbra: Almedina, 2000.

CARDONA, Angela M. A. Breves considerações sobre a situação migratória de estrangeiros bolivianos no Brasil. Justiça do Trabalho, Porto Alegre: H S, ano 23, n. 274, out. 2006.

CASSAR, Vólia Bomfim. Aplicação da legislação do trabalho no espaço. Revista LTr, São Paulo: LTr, ano 67, n. 7, 2003.

CUNHA, Rodrigo Giostri da. Contrato internacional de trabalho - Transferência de empregados. Disponível em: <http://www.socejur.com.br/artigos/direito_internacional.doc>. Acesso em: 15 out. 2006, p. 03.

DALLEGRAVE NETO, José Affonso. Conflito de leis trabalhistas no espaço. Síntese Trabalhista, Porto Alegre: Síntese, n. 130, 2000, p. 69.

DELGADO, Mauricio Godinho. Principios de Direito Individual e Coletivo do Trabalho. São Paulo: LTr, 2010.

DWORKIN, Ronald. Levando os direitos a sério. São Paulo: Martins Fontes, 2002.

ESTRADA, Manuel Martin Pino. O teletrabalho transfronteiriço no Direito brasileiro e a globalização. Disponível em <http:/ / www.conjur.com.br/2002-dez-30/teletrabalho transfronteiriço direito brasileiro> Acesso em: 13 set. 2011.

FREITAS, Juarez. A interpretação sistemática do direito. São Paulo: Malheiros, 2010.

O controle dos atos administrativos e os princípios fundamentais. São Paulo: Malheiros, 2004.

HARDT, Michael. An Apprenticeship in Philosophy. Minneapolis: University of Minnesota Press, 1993, p. 16. Ver mais em: http://philosophersdesk.blogspot.com.br/2008/04/hardt-m-gilles-deleuzeapprenticeship.html\#sthash.kUssgoJL.dpuf

IANNI, Octavio. A sociedade global. Rio de Janeiro: Civilização Brasileira, 2002.

JOHNSON, David R; POST, David G. Law and Borders: The Rise of Law in Cyberspace. Stanford Law Review, Vol. 48, p. 1367, 1996. Disponível em: http://ssrn.com/abstract=535 or http://dx.doi.org/10.2139/ssrn.535. Acesso em: 18 nov. 2013.

LÉVY, Pierre. Cibercultura. Traduzido por Carlos Irineu da Costa. São Paulo: Editora 34, 1999.

O que é o virtual? Traduzido por Paulo Neves. São Paulo: Editora 34, 1996.

LONGHI, Dânia Fiorin. Teoria do Conglobamento - Conflito de Normas no Contrato de Trabalho. São Paulo: LTr, 2009 .

MACHADO, Jorge Alberto. O Ciberespaço como Arquitetura da Liberdade - Tentativas de Territorialização e Controle na Rede. In: ALVES, Giovanni; MARTINEZ, Vinicio (Org.). Dialética do Ciberespaço: Trabalho, Tecnologia e Política no Capitalismo Global. Bauru: Document Arminda, 2002. 
MAGANO, Octavio Bueno. Conflito de leis trabalhistas no espaço (lineamentos). Revista LTr, São Paulo: LTr, ano 51, n. 8, ago. 1987.

MALLET, Estêvão. Conflito de leis trabalhistas no espaço e globalização. Revista LTr, São Paulo: LTr, ano 62, n. 3, p. 330-333, mar. 1998.

MARTINS, Sergio Pinto. Comentários às súmulas do TST. 5. ed. São Paulo: Atlas, 2008.

Direito do trabalho. São Paulo: Atlas, 2005.

MASSANI, Túlio Oliveira. Novas tecnologias no processo jurisdicional do trabalho. Revista LTr, São Paulo: LTr, ano 69, n. 10, out. 2005.

MAYANS, Joan. Ciberespacio: notas para la utilización de un concepto analítico en ciências sociales. In: ALVES, Giovanni; MARTINEZ, Vinicio (Org.). Dialética do Ciberespaço: Trabalho, Tecnologia e Política no Capitalismo Global. Bauru: Document Arminda, 2002.

MELLO, Christiane Bernardes de Carvalho. Direito Internacional Privado e relação jurídica de trabalho: aspectos da legislação brasileira. São Paulo: LTr, 2005.

MONTEIRO, Silvana Drumond. O Ciberespaço: o termo, a definição e o conceito. In: Revista de Ciência da Informação. Londrina: Revista de Ciência da Informação, v. 8, n. 3, jun. 2007. Disponível em < http://dgz.org.br/jun07/Art_03.htm> Acesso em: 02 nov. 2011.

NASCIMENTO, Amauri Mascaro. Curso de direito do trabalho: história e teoria geral do direito do trabalho: relações individuais e coletivas do trabalho. São Paulo: Saraiva, 2005.

Curso de direito do trabalho: história e teoria geral do direito: relações individuais e coletivas do trabalho. São Paulo: Saraiva, 2003.

OLIVARES, Raquel Serrano. Reflexiones en torno a la ley aplicable al ciberempleo transnacional. In: GUANTER, Salvador Del Rey; PARRA, Manuel Luque (Coord.) Relaciones Laborales y Nuevas Tecnologías. Madrid: La Ley, 2005, p. 411-514.

PERES, Antonio Galvão. Contrato internacional de trabalho: novas perspectivas. São Paulo: LTr, 2004.

PINHEIRO, Patrícia Peck. Direito Digital. São Paulo: Saraiva, 2009.

SANTAELLA, Lucia. Navegar no ciberespaço: o perfil cognitivo do leitor imersivo. São Paulo: Palus, 2004

SHIELDS, Rob. The virtual. Nova York: Routledge, 2003.

SILVA, Luís Virgílio Afonso da. O proporcional e o razoável. Revista dos Tribunais, São Paulo, v. 91, n. 798, abr. 2002.

STRENGER, Irineu. Direito Internacional Privado. São Paulo: LTr, 1996.

SUSSEKIND, Arnaldo. Direito Internacional do Trabalho. São Paulo: LTr, 2000.

SUSSEKIND, Arnaldo; MARANHÃO, Délio; VIANNA, Segadas. Instituições de direito do trabalho. 9. ed. ampl. e atual. Rio de Janeiro: Freitas Bastos, 1984.v. 1. 
TEIXEIRA, Eduardo Didonet; HAEBERLIN, Martin. A proteção da privacidade: sua aplicação na quebra do sigilo bancário e fiscal. Porto Alegre: Fabris, 2005.

VALLADÃO, Haroldo. Direito Internacional Privado: conflitos de leis comerciais, cambiais, falimentares, marítimas, aeroespaciais, industriais, trabalhistas, processuais, penais, administrativas, fiscais e eclesiásticas. Rio de Janeiro: Freitas Bastos, 1978. v. 3.

Direito Internacional Privado: em base histórica e comparativa, positiva e doutrinária, especialmente dos Estados americanos. Rio de Janeiro: Freitas Bastos, 1980.v. 1.

VECCHI, Ipojucan Demétrius. Noções de direito do trabalho: um enfoque constitucional. Passo Fundo: UPF, 2004. v. 1.

Trabalho enviado em 19 de julho de 2015.

Aceito em 19 de agosto de 2015. 